\title{
Determinants of Foreign Direct Investment in SAARC Countries: An Investigation Using Panel VAR Model
}

\author{
*Rudra P. Pradhan, Devdut Saha \\ Vinod Gupta School of Management, Indian Institute of Technology Kharagpur, India \\ *rudrap@vgsom.iitkgp.ernet.in
}

\begin{abstract}
Foreign direct investment (FDI) is considered to be a policy variable to enhance economic growth in the economy. So identifying the determinants of FDI is very challenging among the policymakers. The paper examines the determinants of foreign direct investment in seven SAARC countries over the period 1980-2010. Using panel VAR model, the paper finds that foreign direct investment are largely influenced by economic growth, exchange rate, inflation, labor population, trade balance, current account balance and long term debt outstanding. The impact of economic growth and exchange rate are bidirectional, while the other factors are unidirectional on FDI inflows.
\end{abstract}

Keywords: FDI, Panel VAR, SAARC

\section{Introduction}

Foreign direct investment (FDI) has been a subject of interest and the core features of globalization in the SAARC countries since the 1990s when most of these countries have liberalized their economies to attract private investments in various business sectors. FDI has an impact on many aspect of a country's economy such as production, prices, employment, economic growth, balance of payments and the market structure. FDI bridges the gap in technology between the foreign country and the host country and efficient transfer and adoption of "best practices" across borders which in turn improves the productivity and growth of the host country (Le and Suruga, 2005; Kok and Ersoy, 2009).

The relationship between foreign direct investment (FDI) and economic growth is a well-studied subject in the development economics literature, shown in terms of both theoretical and empirical approach. Recently, renewed interest in growth determinants and the considerable research on externality-led growth, with the advent of endogenous growth theories (Barro, 1991; Barro and Sala-i-Martin, 1995), made it more plausible to conclude FDI as one of the determinants of long run economic growth (see Figure 1). There are conflicts among the researchers, whether FDI promotes economic growth or not. On one hand, FDI is being seen, by many, as an important element of solution to the problem of scarce local capital and overall low productivity in many developing countries (De Mello, 1999). Hence, the flow of foreign direct investment is argued to be a potential growth-enhancing player in the host country. This view is challenged by many other authors. For instance, Carkovic and Levine (2002) shows that there is no robust impact from FDI on growth if countryspecific level differences, endogeneity of FDI inflows and convergence effects are taken into account. This is also supported by Akinlo (2004), who finds both private capital and foreign capital have no substantial impact on economic growth.

The industries in the South Asian countries like India, Pakistan, Sri Lanka and Bangladesh are now under pressure to speed up their productivity in order to compete in the global market. The process of initiation has been started after economic reforms in the region during the 1990s; in order to make an attempt for a systematic shift towards an open economy along with privatization of a large segment of the economy. The removals of quantitative barriers in a phased manner, applying the suitable tax policy, and land acquisition policy, etc., have opened up the Indian economy to international market forces which has led to the rapid emergence of a highly competitive environment; especially in the industrial and services sector (Behera and Parida, 2010). This has again emphasized the importance of continuous improvement in productivity, efficiency and technology spillovers of the different sectors in the SAARC countries. The effects of FDI although are confirmed as positive for most of the countries, but the degree of such impact depends on the 
absorptive capacity of host country, which includes the level of human capital, infrastructure, financial and institutional development and trade policies (Makki and Somwaru, 2004).

Figure 1: Linkage between Foreign Direct Investment and Economic Growth

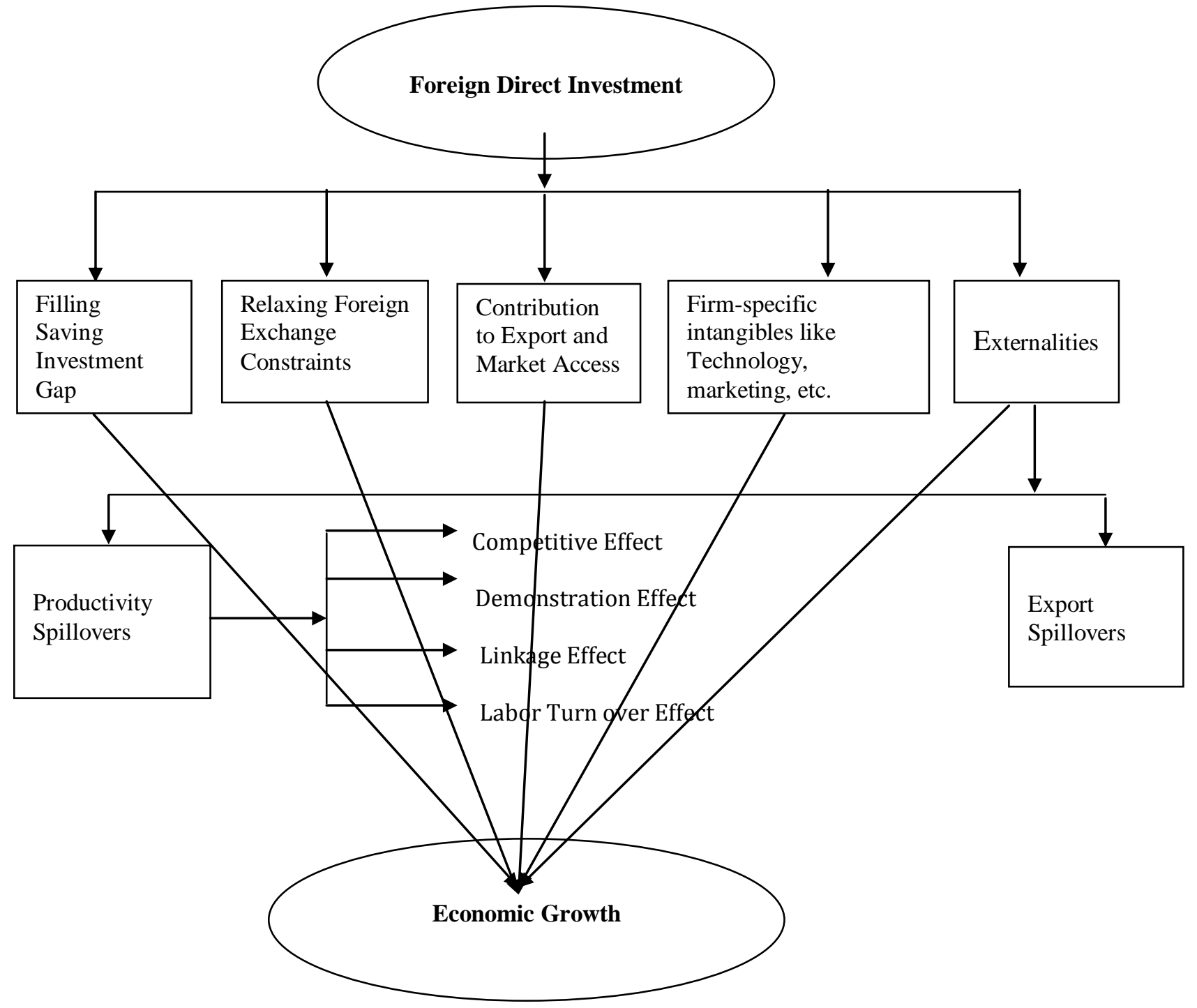

There have been many theoretical and empirical analyses on defining the determinants of FDI. It varies from region to region and largely affected by different policy issues. The major determinants that affect the foreign direct investment are GDP, inflation, balance of payment, labor population, technology gap, market size, infrastructure index, trade openness, exchange rate, domestic investment, debt outstanding, tax rate and so forth (see Jaumotte, 2004; Tang et al, 2008, Pradhan, 2008; Alba et al, 2009; Asiedu 2005; Quattara 2005; Wang, 2002; Carstensen and Toubal, 2004; Aspergis et al, 2006; Frenkel et al, 2004; Anop, 2010; Kok and Ersoy, 2009, Sahoo, 2006; Walsh and Yu, 2010; Alam and Zubayer, 2010). The objective of this paper is to revisit the determinants of FDI in the SAARC countries. The rest of the paper is organized as follows: section 2 describes literature review, section 3 provides database and methodology, section 4 analyses the results, and section 5 provides conclusion.

\section{Literature Review}

Several literatures discuss the various determinants of FDI. The approach towards the identification and empirical analysis of the determinants of FDI can be classified into two parts: production function approach 
and time series approach. The production function approach focuses on the supply potential of an economy and has the advantage of giving a more direct link to economic theory. However, the disadvantage is that it requires assumptions on the functional form of the production technology, returns to scale, trend technical progress and the representative utilization of production factors. The time series approach is popular for estimating the process that underlies some output, or for forecasting from some observed behavior over time. Time series analysis comprises methods for analyzing time series data in order to extract meaningful statistics and other characteristics of the data. This paper intends to concentrate on the time series approach for identification and empirical analysis of the determinants of foreign direct investment. There has been several research works on the time series analysis approach regarding the determinants of FDI. Some of the major literatures are discussed here as follows.

Vita and Kyaw (2008), having study on 32 developing countries, indicated that while for FDI flows to developing countries domestic productivity growth is the dominant determinant, for portfolio flows, domestic money growth is the major 'pull factor'. Behera and Parida (2010) analyzed the spillover effect of Foreign Direct investment (FDI) and determinants of FDI across Indian manufacturing industries. By using Pedroni cointegration tests, they found the long-run relationship between endogenous variables and explanatory variables, which further added to technology spillovers across Indian manufacturing industries. The study found that labor productivity and market size were the major determinants for the FDI inflows into the Indian manufacturing industries. This is also supported by the study of Asiedu (2005), who found natural resources and large markets were mainly promote the FDI inflows in the economy. Moreover, the other factors that have substantial impact on FDI inflows were inflation, infrastructure, skilled labor, trade openness, corruption, political stability and reliable legal system.

Quattara (2005) investigated the determinants of private investments in Senegal and found that public investment and real income positively affect the private investments while the impact of credit to private sector and terms of trade was negative. Carstensen and Toubal (2004) examined the determinants of FDI in Central and European countries and found that traditional determinants like market potential, low relative unit labor costs, skilled workforce and relative endowments had significant and plausible effect. In addition, transition-specific factors like the level and method of privatization and country risk play important roles in determining the flows of FDI. Anop (2010) have examined the determinants of FDI in real estate in European countries through panel data analysis. The study found that the size of the GDP, human capital and road infrastructure appear to be robust under different specifications. Kok and Ersoy (2009), having an attempt to study the best determinants of FDI in developing countries, found that FDI had strong positive effect on economic progress in the developing countries while the interaction of FDI with the total debt service/ GDP and inflation had a negative impact. Alba et al (2009) found the evidence that FDI is interdependent over time and under a favorable FDI environment, the exchange rate has a positive and significant effect on the average rate of FDI inflows. This study is somewhat similar to Tang et al (2008), who found that FDI had a complementary relationship with domestic investment.

Jaumotte (2004) found that the market size of a regional trade agreement (RTA) is a determinant of FDI received by countries participating in RTA. A partial negative correlation between the FDI received by RTA countries and that received by non-RTA countries was found that reflects a diversification of FDI from nonRTA to RTA countries. The paper also cited example of FDI benefits that are stimulated from the creation of a regional trade agreement between Algeria, Morocco and Tunisia. Sahoo (2006) did panel cointegration test on the determinants of FDI in the South Asia. The study found that FDI and its determinants have long run equilibrium relationship. The major determinants of FDI in South Asia are market size, labor force growth, infrastructure index and trade openness. The results of FDI impact on growth show that FDI has a positive and significant impact on growth for four south Asian countries. Other significant factors that contribute to growth are exports, gross domestic capital formation and infrastructure. Vijayakumar et al (2010) examined the factors determining the FDI inflows in BRICS countries and found that market size, labor cost, infrastructure, currency value and gross capital formation are the potential determinants of FDI. The Economic Stability and Growth prospects (measured by inflation rate and Industrial production respectively), Trade openness (measured by the ratio of total trade to GDP) are seems to be the insignificant determinant of FDI inflows of the BRICS countries. 
Faeth (2005) examined the determinants of FDI in Australia. FDI inflows are explained using market size, factor costs, transport costs and protection, risk factors, policy variables and other factors, i.e. variables based on a number of different theoretical models. It was found that Australian FDI is driven by longer term considerations and its determinants could not be fully explained by any single theoretical model. Exchange rate appreciation discouraged FDI in the medium-term, but had a positive longer term effect, indicating that FDI is encouraged by a sound economic environment. There was, however, no evidence that lower corporate tax rates increased FDI inflows. Tsen (2005) examined the determinants of FDI in the manufacturing sector of Malaysia. The results of the cointegration test found that education, infrastructure, market size or current account balance are the determinants of FDI. Increase in inflation and exchange rate decreases the FDI inflow. Sowkut et al (2008) studied the FDI flows in Africa and found that the abundance of natural resources is reported to be positive and significant (supporting the presence of resource-seeking FDI) and is line with Aseidu (2002). Openness had a positive impact on FDI as well and is in line with the fact that an efficient environment that comes with more openness to trade is likely to attract foreign firms. The size of the domestic market, stock of human capital, though to a large extent as witnessed by the size of their respective coefficients, played a positive role while political instability and labor cost a negative role in attracting FDI in the markets and the results are consistent with empirical works in the field.

\section{Data and Methodology}

In this section, we discuss the database and the details of methodology.

Database: To examine the determinants of FDI, we use annual data set of seven SAARC countries such as Bangladesh, Bhutan, India, Nepal, Pakistan, Sri Lanka and Maldives from 1980-2010. The variables that used in the study are GDP, Labor population, GDP Per capita (indicates market size), Inflation (GDP deflator), Exchange rate (with respect to USD), Current account balance, Merchandise trade balance and long term debt outstanding. The data are obtained from IMF's International Financial Statistics database, World databank and UNCTAD statistics and are expressed in natural logarithms. To examine the determinants of FDI in SAARC countries, we follow the standard methods of Granger causality test (as in, for example, Granger [1988] and Granger [1981]). But the precondition to Granger causality test is integration and cointegration properties of the relevant time series variables (see Johansen, 1988). That means there are three tests through which we can study the determinants of FDI: first, test for order of integration; second, test for cointegration; third, test for Granger causality. We apply all these three tests at the panel level. These techniques are described below.

Unit Root Test: The Augmented Dickey Fuller (Dickey et al., 1981) unit root test is generally used to detect the order of integration of time series variables at the individual country analysis. But the traditional Augmented Dickey Fuller (ADF) unit root test suffers the problem of low power in rejecting the null hypothesis of stationarity of the time series, particularly for small size of data. To resolve this issue, we use LLC (Levin et al., 2002) and IPS (Im et al., 2003) panel unit root tests. These two tests have higher power than the unit root test based on individual time series. Both LLC and IPS are very popular and both are based on the lines of ADF principles. The LLC assumes homogeneity in the dynamics of the autoregressive coefficients for all panel numbers, while IPS assumes heterogeneity in these dynamics. LLC proposes a panel-base augmented Dickey-Fuller (ADF) test with a panel setting and restricts $\gamma$ to keep it identical across crosssectional regions. The test imposes homogeneity on the autoregressive coefficient that indicates the presence or absence of a unit root whereas the intercept and trend may vary across individual series. The model allows heterogeneity only in the intercept and is given by

$$
\Delta Y_{i, t}=\alpha_{i}+\gamma Y_{i, t-i}+\sum_{j=1}^{p_{i}} \beta_{j} \Delta Y_{i, t-j}+\varepsilon_{i, t}
$$

where $Y_{i, t}$ is a series for panel member (country) $i(i=1,2, . . N)$ over period $t(t=1,2, \ldots T)$, and $p_{i}$ is the number of lags in the ADF regression. The error term $\left(\varepsilon_{i, t}\right)$ are assumed to be IID $\left(0, \sigma^{2}\right)$ and to be independent across the units of the sample. The model allows for fixed effects, unit specific time trends, and common time effects. The coefficient of the lagged dependent variable is restricted to be homogenous across all units of the panel. Hence, the null hypothesis of non-stationary is stated as:

$\mathrm{H}_{0}: \gamma_{\mathrm{i}}=0$, is tested against the alternative,

$\mathrm{H}_{\mathrm{A}}: \gamma_{\mathrm{i}}=\gamma<0$ for all $\mathrm{i}$ 
The fixed effect model in eq. (1) is based on the usual t-statistic.

$t_{\gamma}=\frac{\hat{\gamma}}{\operatorname{s.e}(\hat{\gamma})}$

where, $\gamma$ is restricted by being kept identical across members of the panel under both the null and alternative hypothesis.

The IPS test begins by specifying a separate ADF regression for each cross section (country):

$$
\Delta Y_{i, t}=\alpha_{i}+\gamma_{i} Y_{i, t-i}+\sum_{j=1}^{p_{i}} \beta_{i, j} \Delta Y_{i, t-j}+\varepsilon_{i, t}
$$

Where series $y_{i t}(i=1,2, \ldots, N ; t=1,2, \ldots, T)$ is the series for panel member (country) $i$ over period, $p_{i}$ is the number of lags in the ADF regression and the error terms $\varepsilon_{i, t}$ are assumed to be IID $\left(0, \sigma_{i}^{2}\right)$ for all $i$ and $t$. Both $\gamma_{\mathrm{i}}$ and the lag order $\beta$ in equation (4) are allowed to vary across sections (countries). IPS relaxes the assumption of homogeneity of the coefficients of the lagged dependent variable. It tests the null hypothesis that each series in the panel has a unit root for all cross-section units against the alternative that at least one of the series is stationary.

$\mathrm{H}_{0}: \gamma_{\mathrm{i}}=0$ for all $\mathrm{i}$, is tested against the alternative,

$\mathrm{H}_{\mathrm{A}}: \gamma_{\mathrm{i}}=\gamma_{\mathrm{i}}<0$ for $\mathrm{i}=1,2, \ldots ., \mathrm{N}_{1}, \gamma_{\mathrm{i}}=0$,

$\mathrm{i}=\mathrm{N}_{1}+1, \mathrm{~N}_{1}+2, \ldots, \mathrm{N}$

The alternative hypothesis simply implies that some or all of the individual series are stationary. IPS developed two test statistics and called them the LM-bar and the t-bar tests. The IPS t-bar statistic is calculated using the average of the individual Dickey-Fuller $\tau$ statics shown below.

$$
\begin{aligned}
& \bar{t}=\frac{1}{N} \sum_{i=1}^{N} \tau_{i} \\
& \tau_{i}=\frac{\hat{\gamma}_{i}}{\operatorname{s.e}\left(\hat{\gamma}_{i}\right)}
\end{aligned}
$$

Assuming that the cross sections are independent, IPS proposes the use of the standardized t-bar statistic.

$$
\bar{Z}=\frac{\sqrt{N}(\bar{t}-E(\bar{t}))}{\sqrt{\operatorname{Var}(\bar{t})}}
$$

The term $E(\bar{t})$ and $\operatorname{Var}(\bar{t})$ here are the mean and variance of $\tau$ statistic.

Co integration Test: Once the order of stationarity has been defined, our next step is to apply panel cointegration test. Granger (1988) showed that when the time series become stationary only after being differenced once, they might have linear combinations that are stationary without differencing. Such series are usually called cointegrated. If integration of order one is implied, the next step is to use cointegartion analysis in order to establish whether there exists a long run relationship among the set of the integrated variables. In this investigation, the Johansen (Johansen, 1988) cointegration test is deployed first to test the existence of long run equilibrium relationship between health expenditure and economic growth at the individual state level. The test follows the estimation of following equation:

$$
Y_{i t}=\beta_{i 0}+\beta_{i 1} X_{i 1 t}+\beta_{i 2} X_{i 2 t}+\ldots .+\beta_{i k} X_{i k t}+\varepsilon_{i t}
$$

But we note that the above test could not deal with panel settings. So, Pedroni (2004) panel cointegration has been used for the same. The test starts with the estimation of parameters of the following panel regression,

$$
\begin{aligned}
& Y_{i, t}=\alpha_{i}+\sum_{j=1}^{p_{i}} \beta_{j i} X_{j i t}+\varepsilon_{i t} \quad \text { and } \\
& \varepsilon_{i t}=\rho_{i} \varepsilon_{i(t-1)}+w_{i t}
\end{aligned}
$$

where $\mathrm{Y}_{\mathrm{it}}$ and $\mathrm{X}_{\mathrm{jit}}$ are the observable variables with dimension of $\left(\mathrm{N}^{*} \mathrm{~T}\right)$ ) $\mathrm{x} 1$ and $\left(\mathrm{N}^{*} \mathrm{~T}\right) \mathrm{x}$ respectively; $\varepsilon_{\mathrm{it}}$ represents the disturbance term from the panel regression; $\alpha_{i}$ would allow for the possibility of countryspecific fixed effects and the coefficients of $\beta_{\mathrm{ji}}$ would allow for the variation across individual countries. The null hypothesis of no cointegration of the pooled (within-dimension) estimation is $H_{0}: \rho_{i}=1$ for all $\mathrm{i}$ against 
$\mathrm{H}_{0}: \rho_{\mathrm{i}}=\rho<1$ for some $\mathrm{i}$. The null hypothesis of no-cointegration of the pooled (between-dimension) estimation is $\mathrm{H}_{0}: \rho_{\mathrm{i}}=1$ for all $\mathrm{i}$ against $\mathrm{H}_{0}: \rho_{\mathrm{i}}<1$. Pedroni suggested two types of tests to determine the existence of heterogeneity of the cointegration vector. First, the test uses within- dimension approach (i.e. panel test). It includes four statistics that are panel $v$ - statistic, panel $\rho$ - statistic, panel PP- statistic and panel ADF- statistic (Pedroni, 1999). These statistics pool the autoregressive coefficients across different members for the unit root tests to be performed on the estimated residuals. Second, the test based on betweendimensional approaches (group test) includes three statistics that are group $\rho$-statistic, group PP-statistic and group ADF-statistic (see Pedroni, 2004). These statistics are calculated as follows:

Panel $v$ - statistic

$Z_{v}=\left[\sum_{i=1}^{N} \sum_{t=1}^{T} \hat{L}_{11 i}^{-2} \hat{\varepsilon}_{i t-1}^{2}\right]^{-1}$

Panel $\rho$ - statistic

$$
Z_{\rho}=\left[\sum_{i=1}^{N} \sum_{t=1}^{T} \hat{L}_{11 i}^{-2} \hat{\varepsilon}_{i t-1}^{2}\right]^{-1} \sum_{i=1}^{N} \sum_{t=1}^{T} L_{11 i}^{-2}\left(\hat{\varepsilon}_{i t-1} \Delta \hat{\varepsilon}_{i t}-\hat{\lambda}_{i}\right)
$$

Panel PP- statistic

$$
Z_{t}=\left[\hat{\sigma}^{2} \sum_{i=1}^{N} \sum_{t=1}^{T} \hat{L}_{11 i}^{-2} \hat{\varepsilon}_{i t-1}^{2}\right]^{-0.5} \sum_{i=1}^{N} \sum_{t=1}^{T} L_{11 i}^{-2}\left(\hat{\varepsilon}_{i t-1} \Delta \hat{\varepsilon}_{i t}-\hat{\lambda}_{i}\right)
$$

Panel ADF- statistic

$$
Z_{t}^{*}=\left[\hat{\boldsymbol{S}}^{*^{2}} \sum_{i=1}^{N} \sum_{t=1}^{T} \hat{\boldsymbol{L}}_{11 i}^{-2} \hat{\varepsilon}_{i t-1}^{* 2}\right]^{-0.5} \sum_{i=1}^{N} \sum_{t=1}^{T} \hat{L}_{11 i}^{-2} \hat{\varepsilon}_{i t-1}^{*} \Delta \hat{\varepsilon}_{i t}^{*}
$$

Group $\rho$ - statistic

$$
\tilde{Z}_{\rho}=\sum_{i=1}^{N}\left(\sum_{t=1}^{T} \hat{\varepsilon}_{i t-1}^{2}\right)^{-1} \sum_{t=1}^{T}\left(\hat{\varepsilon}_{i t-1} \Delta \hat{\varepsilon}_{i t}-\hat{\lambda}_{i}\right)
$$

Group PP- statistic

$$
\tilde{Z}_{t}=\sum_{i=1}^{N}\left(\hat{\sigma}^{2} \sum_{t=1}^{T} \hat{\varepsilon}_{i t-1}^{2}\right)^{-0.5} \sum_{t=1}^{T}\left(\hat{\varepsilon}_{i t-1} \Delta \hat{\varepsilon}_{i t}-\hat{\lambda}_{i}\right)
$$

Group ADF- statistic

$$
\tilde{Z}_{t}^{*}=\sum_{i=1}^{N}\left(\sum_{t=1}^{T} \hat{s}_{i}^{2} \hat{\varepsilon}_{i t-1}^{* 2}\right)^{-0.5} \sum_{t=1}^{T}\left(\hat{\varepsilon}_{i t-1}^{*} \Delta \hat{\varepsilon}_{i t}^{*}\right)
$$

where, $\hat{\varepsilon}_{i t}$ is the estimated residual from equation (10) and $\hat{L}_{11 i}^{-2}$ is the estimated long run covariance matrix for $\Delta \hat{\varepsilon}_{i t}$. Similarly, $\hat{\sigma}_{i}^{2}$ and $\hat{s}_{i}^{2}\left(\hat{s}_{i}^{* 2}\right)$ are the long run and contemporaneous variances for individual i. All seven tests are based asymptotically standard normal distributions given by the respective panel/ group cointegration statistic. The panel $v$ is a one sided test where large positive values reject the null hypothesis of no cointegration. The other remaining statistics diverge to negative infinite, which means that large negative values reject the null hypothesis. Each of these tests is able to accommodate individual specific short-run dynamics, individual specific fixed effects and deterministic trends as well as individual specific slope coefficients (Pedroni, 2004).

Granger Causality Test: The following panel VAR (Holtz- Eakin et al., 1988) is considered:

Model 1: If the time series variables are 1 (1) and not cointegrated, we can use the following causality model: 


$$
\begin{aligned}
& \Delta F D I_{i t}=\eta_{j}+\sum_{k=1}^{n} \alpha_{1 i k} \Delta F D I_{i t-k}+\sum_{k=1}^{n} \alpha_{2 i k} \Delta E R_{i t-k}+\sum_{k=1}^{n} \alpha_{3 i k} \Delta I N F_{i t-k}+\sum_{k=1}^{n} \alpha_{4 i k} \Delta L P_{i t-k} \\
& +\sum_{k=1}^{n} \alpha_{5 i k} \Delta G D P_{i t-k}+\sum_{k=1}^{n} \alpha_{6 i k} \Delta M T B_{i t-k}+\sum_{k=1}^{n} \alpha_{7 i k} \Delta C A B_{i t-k}+\sum_{k=1}^{n} \alpha_{8 i k} \Delta L T D_{i t-k}+\Delta \varepsilon_{i t}
\end{aligned}
$$

where, FDI is Foreign Direct Investment; ER is Exchange Rate; INF is Inflation rate; LP is Labor population, GDP is Per Capita Gross Domestic Product; MTB is Merchandise Trade Balance; CAB is Current Account Balance; and LTD is Long Term Debt Outstanding.

Model 2: If the time series variables are 1 (1) and cointegrated, then the causality is tested by using error correction model. This is represented as follows:

$$
\begin{aligned}
& \Delta F D I_{i t}=\eta_{j}+\sum_{k=1}^{n} \alpha_{1 i k} \Delta F D I_{i t-k}+\sum_{k=1}^{n} \alpha_{2 i k} \Delta E R_{i t-k}+\sum_{k=1}^{n} \alpha_{3 i k} \Delta I N F_{i t-k}+\sum_{k=1}^{n} \alpha_{4 i k} \Delta L P_{i t-k} \\
& +\sum_{k=1}^{n} \alpha_{5 i k} \Delta G D P_{i t-k}+\sum_{k=1}^{n} \alpha_{6 i k} \Delta M T B_{i t-k}+\sum_{k=1}^{n} \alpha_{7 i k} \Delta C A B_{i t-k}+\sum_{k=1}^{n} \alpha_{8 i k} \Delta L T D_{i t-k}+\Gamma_{i} E C_{1 i t-k}+\Delta \varepsilon_{i t}
\end{aligned}
$$

(20)

where EC is the error correction term, obtained from the cointegrating equation.

\section{Results and Discussion}

In this section we study the Granger causality among foreign direct investment, trade openness and economic growth. The analysis starts with the stationarity properties of the data series. This is the prime requirement for cointegration and causality test. Table 1 presents the results of unit root tests. The results find that time series variables, such as foreign direct investment, exchange rate, inflation, labor population, per capita gross domestic product, merchandise trade balance, current account balance and long term debt outstanding, are having unit roots at the level data. This is because the estimated unit root test statistics cannot reject the null hypothesis of non-stationarity at $10 \%$ level of significance. However, they are stationary at the first difference level, as the null hypothesis of non-stationarity is rejected at $5 \%$ level of significance (see Table 1). This confirms that the variables are integrated of order one, 1 (1).

Table 1: Results of Unit Root Test (At First Difference)

\begin{tabular}{lcclcccc}
\hline \multirow{2}{*}{ Variables } & \multicolumn{9}{c}{ C } & \multicolumn{1}{c}{ C + T } & \multirow{2}{*}{ Inferences } \\
\cline { 2 - 6 } & IPS & ADF & PP & IPS & ADF & PP & \\
\hline FDI & $-28.497^{*}$ & $-28.497^{*}$ & $-34.444^{*}$ & $-28.402^{*}$ & $-28.402^{*}$ & $-34.380^{*}$ & I (1) \\
ER & $-12.750^{*}$ & $-12.749^{*}$ & $-12.749^{*}$ & $-12.707^{*}$ & $-12.707^{*}$ & $-12.707^{*}$ & I (1) \\
INF & $-10.463^{*}$ & $-10.463^{*}$ & $-154.164^{*}$ & $-10.428^{*}$ & $-10.428^{*}$ & $-154.834^{*}$ & I (1) \\
LP & $-12.331^{*}$ & $-12.331^{*}$ & $-12.331^{*}$ & $-12.291^{*}$ & $-12.291^{*}$ & $-12.291^{*}$ & I (1) \\
GDPC & $-10.463^{*}$ & $-10.463^{*}$ & $-30.369^{*}$ & $-10.430^{*}$ & $-10.430^{*}$ & $-30.431^{*}$ & I (1) \\
MTB & $-12.595^{*}$ & $-12.595^{*}$ & $-12.598^{*}$ & $-12.560^{*}$ & $-12.560^{*}$ & $-12.563^{*}$ & I (1) \\
CAB & $-10.096^{*}$ & $-10.096^{*}$ & $-119.074^{*}$ & $-10.062^{*}$ & $-10.062^{*}$ & $-119.879^{*}$ & I (1) \\
LTD & $-12.476^{*}$ & $-12.476^{*}$ & $-12.476^{*}$ & $-12.439^{*}$ & $-12.439^{*}$ & $-12.439^{*}$ & I (1) \\
\hline
\end{tabular}

Note: FDI: Foreign Direct Investment; ER: Exchange Rate; INF: Inflation; LP: Labor population, GDP: Per Capita Gross Domestic Product; MTB: Merchandise Trade Balance; CAB: Current Account Balance; LTD: Long Term Debt Outstanding; C: Constant; C+T: Constant plus Trend; IPS: IPS statistics; PP: PP statistics; ADF: Augmented Dickey Fuller Test; I (1): Integrated of order one; and *: Indicates statistically significant at 5\% level 
Table 2: Results of Cointegration Test

\begin{tabular}{lllllll}
\hline \multirow{2}{*}{$\begin{array}{c}\text { No. of Cointegrating } \\
\text { eqn(s) }\end{array}$} & \multicolumn{3}{c}{ Trace Statistics } & \multicolumn{3}{c}{ Maximum Eigen Value Statistics } \\
\cline { 2 - 7 } & \multicolumn{1}{c}{$\begin{array}{c}\text { Trace } \\
\text { statistics }\end{array}$} & $\begin{array}{c}\mathbf{0 . 0 5} \text { critical } \\
\text { value }\end{array}$ & Prob & $\begin{array}{c}\text { Max-Eigen } \\
\text { statistics }\end{array}$ & $\begin{array}{c}\text { 0.05 critical } \\
\text { value }\end{array}$ & Prob \\
\hline None & $232.47^{*}$ & 159.53 & 0.00 & 77.92 & 52.36 & 0.00 \\
At most 1 & $154.55^{*}$ & 125.61 & 0.00 & 46.55 & 46.23 & 0.05 \\
At most 2 & 108.00 & 95.75 & 0.01 & 32.03 & 40.08 & 0.30 \\
At most 3 & 75.97 & 69.82 & 0.01 & 26.26 & 33.88 & 0.31 \\
At most 4 & 49.70 & 47.86 & 0.03 & 23.71 & 27.58 & 0.15 \\
At most 5 & 25.99 & 29.79 & 0.13 & 15.97 & 21.13 & 0.23 \\
At most 6 & 10.02 & 15.49 & 0.28 & 8.262 & 14.26 & 0.35 \\
At most 7 & 1.753 & 3.841 & 0.19 & 1.753 & 3.841 & 0.19 \\
\hline
\end{tabular}

Note: *: Indicates statistically significant at 5\% level.

Having confirmed the existence of unit roots for all the data series, the next step is to check the existence of long run equilibrium relationship between them. The Pedroni's panel cointegration test is applied for the same. The estimated results of panel cointegration tests (Pedroni's test) are reported in Table 2. The results find that there is cointegration between foreign direct investment, exchange rate, inflation, labor population, per capita gross domestic product, merchandise trade balance, current account balance and long term debt outstanding at the panel of seven SAARC countries. That means the results confirmed that foreign direct investment and its determinants, share a long run equilibrium relationship in the SAARC countries. That means there is possibility of causality between foreign direct investment and its determinants such as exchange rate, inflation, labor population, per capita gross domestic product, merchandise trade balance, current account balance and long term debt outstanding. We use Error Correction Model (ECM) to know the direction of causality between foreign direct investment and its determinants.

Table 3: Results of Granger Panel Causality Test

\begin{tabular}{|c|c|c|c|c|c|c|c|c|}
\hline \multirow{2}{*}{$\begin{array}{l}\text { Independent } \\
\text { Variables }\end{array}$} & \multicolumn{8}{|c|}{ Dependent Variables } \\
\hline & $\Delta$ FDI & $\Delta \mathrm{ER}$ & $\Delta \mathrm{INF}$ & $\Delta \mathrm{LP}$ & $\Delta \mathrm{LTD}$ & $\triangle \mathrm{CAB}$ & $\Delta \mathrm{MTB}$ & $\triangle$ GDPC \\
\hline$\Delta$ FDI & --- & $12.75^{*}$ & 4.983 & 9.116 & 7.572 & 6.099 & 8.109 & $25.73^{*}$ \\
\hline$\Delta \mathbf{E R}$ & $57.86^{*}$ & --- & 6.492 & 11.62 & 14.22 & 11.31 & 13.99 & $45.45^{*}$ \\
\hline$\Delta \mathrm{INF}$ & $11.92 *$ & $17.45^{*}$ & --- & 7.471 & 13.15 & 9.675 & 6.548 & 12.41 \\
\hline$\Delta \mathbf{L P}$ & $80.98^{*}$ & 17.93* & 6.165 & --- & 11.41 & 8.623 & 10.19 & $51.07^{*}$ \\
\hline$\Delta$ LTD & $61.36^{*}$ & 18.85 & 7.792 & 7.682 & --- & 13.10 & 11.49 & $21.74^{*}$ \\
\hline$\triangle \mathrm{CAB}$ & $43.55^{*}$ & $27.73^{*}$ & 6.067 & 63.868* & $69.51 *$ & --- & $19.73^{*}$ & $40.43^{*}$ \\
\hline$\Delta$ MTB & $15.55^{*}$ & $15.34^{*}$ & $34.55^{*}$ & 12.463 & 11.83 & $22.92^{*}$ & --- & $16.31^{*}$ \\
\hline$\triangle G$ GPC & $36.08^{*}$ & 8.407 & 7.609 & 4.644 & 5.065 & 6.295 & 6.289 & --- \\
\hline EC & 0.251 & 0.169 & -0.745 & 3.292 & $3.475^{*}$ & 0.479 & -3.052 & $-5.81 *$ \\
\hline
\end{tabular}

Note: $\Delta$ : Difference Operator; FDI: Foreign Direct Investment; ER: Exchange Rate; INF: Inflation; LP: Labor population, GDP: Per Capita Gross Domestic Product; MTB: Merchandise Trade Balance CAB: Current Account Balance; LTD: Long Term Debt Outstanding; EC: Error Correction Term; and *: Indicates statistically significant at $5 \%$ level.

The Table 3 presents the results of panel causality test. The results showed that the factors such as exchange rate, inflation, labor population, per capita gross domestic product, merchandise trade balance, current account balance and long term debt outstanding are significant impact on FDI in seven SAARC countries. Besides, we also find that FDI affects exchange rate and economic growth. That means there is bidirectional causality between foreign direct investment and exchange rate and foreign direct investment and economic growth, which is similar to the study by Aizenman and Noy (2006). But in other case, there is presence of unidirectional causality between foreign direct investment and its determinants.

\section{Conclusion and Policy Implications}

The present work examines the determinants of foreign direct investment in the seven SAARC countries over the period 1980-2010. Using panel cointegration, it suggests the following findings: 
- Foreign direct investment, exchange rate, inflation, labor population, per capita gross domestic product, merchandise trade balance, current account balance and long term debt outstanding are integrated of order one for the seven SAARC countries, namely Bangladesh, Bhutan, India, Nepal, Pakistan, Sri Lanka and Maldives.

- Pedroni's panel cointegration test confirmed the existence of a long run equilibrium relationship between foreign direct investment, exchange rate, inflation, labor population, per capita gross domestic product, merchandise trade balance, current account balance and long term debt outstanding.

- The Granger causality finds the presence of bidirectional causality between foreign direct investment and exchange rate and foreign direct investment and economic growth. But for other determinants, there is presence of unidirectional causality only.

The results suggest foreign direct investment are largely influenced by exchange rate, inflation, labor population, per capita gross domestic product, merchandise trade balance, current account balance and long term debt outstanding. That means the policy implications are very straightforward. To get more foreign direct investment in the economy, we need to have higher economic growth, stability in exchange rate and inflation rate, more labor population growth, better trade openness, and stability in current account balance and long term debt outstanding. The lack of same may affect the FDI inflows in the economy. So the piecemeal approach to such a vital objective is of serious consequences. What is urgently required is to follow an appropriate policy measures so that we can address the problems in a right earnest.

\section{References}

Aizenman, J. \& Noy, I. (2006). FDI and Trade: Two Way Linkages. Quarterly Review of Economics and Finance, 46, 317-337.

Akinlo, A. (2004). Foreign Direct Investment and Growth in Nigeria: An Empirical Investigation. Journal of Policy Modeling, 26, 627-639.

Alam, M. S. \& Zubayer, M. (2010). Intra Regional Foreign Direct Investment (FDI) Prospect in South Asian Association of Regional Cooperation (SAARC) Region. International Journal of Economics and Finance, 2, 114-121.

Alba, J. D., Park, D. \& Wang, P. (2009). The Impact of Exchange Rate on FDI and the Interdependence of FDI over time. ADB Economics working paper series, 164, Asian Development Bank, Manila.

Anop, S. (2010). Determinants of Foreign Direct Investment in Real Estate in European Countries- Panel Data Analysis. 17th Annual European Real Estate Society Conference in Milan, Italy.

Asiedu, E. (2002). On the Determinants of Foreign Direct Investment to Developing Countries: Is Africa Different? World Development, 30, 107-118.

Asiedu, E. (2005). Foreign Direct Investment in Africa: The Role of Natural Resources, Market Size, Government Policy, Institutions and Political Instability. World Institute for Development Economics Research, 2005/2,4. UNU- WIDER, Finland.

Aspergis, N., Katrakilidis, C. P. \& Tabakis, N. M. (2006). Dynamic Linkages between FDI Inflows and Domestic Investment: A Panel Cointegration Approach. Atlantic Economic Journal, 34, 385-394

Barro, R. J., (1991). Economic Growth in a Cross Section of Countries. Quarterly Journal of Economics, 106, 407- 443.

Barro, R. J., \& Sala-I-Martin, X. (1995). Economic Growth. Cambridge, MA: NBER.

Behera, S. R. \& Parida, Y. (2010). Technology Spillovers and Determinants of Foreign Direct Investment: Evidence across Indian Manufacturing Industries. Paper presented in the Money and Finance Conference during February 25-26, 2011 at Indira Gandhi Institute of Development Research, Mumbai.

Carkovic, M. \& Levine, R. (2002). Does Foreign Direct Investment Accelerate Economic Growth? Working paper, Minneapolis: University of Minneapolis.

Carstensen, K. \& Toubal, F. (2004). Foreign Direct Investment in Central and Eastern European countries: A Dynamic Panel Analysis. Journal of Comparative Economics, 32, 3-22

De Mello, L. R. (1999). Foreign Direct Investment Led Growth: Evidence from Time Series and panel Data. Oxford Economic Papers, 51, 133-151. 
Dickey, D. A., \& Fuller, W. A. (1981). Likelihood Ratio Statistics for Autoregressive Time Series with a Unit Root. Econometrica, 49, 1057-1072.

Faeth, I. (2005). Determinants of FDI in Australia: Which Theory can Best Explain it? Working Paper Series, 946. University of Melbourne, Australia.

Frenkel, M., Funke, K. \& Stadtmann, G. (2004). A Panel Analysis of Bilateral FDI Flows to Emerging Economies. Economic systems, 28, 281-300.

Granger, C. W. J. (1981). Some Properties of Time Series Data and Their Use in Econometric Model Specification. Journal of Econometrics, 16, 121-130.

Granger, C. W. J. (1988). Some Recent Developments in a Concept of Causality. Journal of Econometrics, 39, 199-211.

Holtz- Eakin, D., Newey, W., \& Rosen, H. S. (1988). Estimating Vector Auto Regressions with Panel Data. Econometrica, 56, 1371-1395.

Im, K. S., Pesaran, M. H., \& Shin, Y. (2003). Testing for Unit Roots in Heterogeneous Panels. Journal of Econometrics, 115, 53-74.

Jaumotte, F. (2004). Foreign Direct Investment and Regional Trade Agreements: The Market Size Effect Revisited. IMF working paper. International Monetary Fund, Washington.

Johansen, S. (1988). Statistical Analysis of Cointegrating Vectors. Journal of Economics Dynamic and Control, $12,231-254$.

Kok, R. \& Ersoy, B. (2009). Analyses of FDI Determinants in Developing Countries. International journal of Social Economies, 36, 105-123

Le, M. V. \& Suruga, T. (2005). The Effects of FDI and Public Expenditure on Economic Growth: From Theoretical Model to Empirical Evidence. GSICS Working Paper Series, 2. Graduate School of International Cooperation Studies, Kobe University, Japan.

Levin, A., Lin, C. F., \& Chu, C. S. (2002). Unit Root Tests in Panel Data: Asymptotic and Finite Sample Properties. Journal of Econometrics, 108, 1-24.

Makki, S. \& Somwaru, A. (2004). Impact of Foreign Direct Investment and Trade on Economic Growth: Evidence from Developing Countries. American Journal of Agricultural Economics, 86, 795-801

Pedroni, P. (1999). Critical values for Cointegration Tests in Heterogeneous Panels with Multiple Regressor. Oxford Bulletin of Economics and Statistics, 61, 653-670.

Pedroni, P. (2004). Panel Cointegration: Asymptotic and Finite Sample Properties of Pooled Time Series Tests with an Application to the PPP Hypothesis: New Results. Econometric Theory, 20, 597-627.

Pradhan, R. P. (2008). Does Economic Growth Promote Foreign Direct Investment? Evidence from India and Malaysia. South Asian Journal of Management, 15, 7-23.

Quattara, B. (2005). Modelling the Long Run Determinants of Private Investment in Senegal. CREDIT Research paper, 04/05. Centre for Research in Economic Development and International Trade, University of Nottingham, UK.

Sahoo, P. (2006). Foreign Direct Investment in South Asia: Policy, Trends, Impact and Determinants. $A D B$ Institute Discussion Paper, No. 56. Asian Development Bank, Manila.

Sowkut, R., Boopen, S., Taruna, R. S. \& Vinesh, S. (2008). Determinants of FDI: Lessons from African Economies. Virtual Institute, UNCTAD, Geneva.

Tang, S., Selvanathan, A. \& Selvanathan, S. (2008). Foreign Direct Investment, Domestic Investment and Economic Growth in China: A Time Series Analysis. The World Economy, 31, 1292-1309.

Tsen, W. H. (2005). The Determinants of Foreign Direct Investment in the Manufacturing Industry of Malaysia. Journal of economic cooperation, 26, 91-110

Vijayakumar, N., Sridharan, P. \& Rao, K. (2010). Determinants of FDI in BRICS Countries: A Panel Analysis. International Journal of Business Science and Applied Management, 5, 1-13.

Vita, G. D. \& Kyaw, K. S. (2008). Determinants of FDI and Portfolio Flows to Developing Countries: A Panel Cointegration Analysis. European Journal of Economics, Finance and Administrative Sciences, 13, 161168.

Walsh, J. P. \& Yu, J. (2010). Determinants of Foreign Direct Investment: A Sectoral and Institutional Approach. IMF Working paper. International Monetary Fund, Washington.

Wang, M. (2002). Manufacturing FDI and Economic Growth: Evidence from Asian Economies. University of Oregon Mimeo, Mimeo. 